P-ISSN 2580 - 7781

E-ISSN 2615 - 3238

\title{
TINJAUAN KUHAP TENTANG PENANGGUHAN PENAHANAN
}

\section{REVIEW OF THE KUHAP CONCERNING SUSPENSION OF DETENTION}

\author{
Tedjo Asmo Sugeng \\ Fakultas Hukum, Universitas Abdurachman Saleh \\ Email : tedjo_asmo_sugeng@unars.ac.id
}

\begin{abstract}
ABSTRAK
Studi penelitian ini membahas tentang bagaimana pelaksanaan penangguhan penahanan menurut KUHAP. Jenis studi penelitian ini adalah jenis normatif. Hasil studi penelitian ini menunjukkan bahwa pelaksanaan penangguhan penahanan dapat berupa jaminan orang atau uang. Dan pemberian penangguhan penahanan sewaktu-waktu dapat dicabut kembali sepanjang tersangka atau terdakwa dikhawatirkan melarikan diri atau melanggar persyaratan yang sudah ditentukan.
\end{abstract}

Kata kunci : KUHAP; Penangguhan Penahanan; Hukum

\begin{abstract}
This research study discusses how to implement suspension of detention according to the Criminal Procedure Code. This type of research study is the normative type. The results of this research study indicate that the implementation of detention suspension can be in the form of a person guarantee or money. And the provision of a suspension of detention at any time can be revoked as long as it is feared that the suspect or defendant will run away or violate the stipulated conditions.
\end{abstract}

Key Words : KUHAP; Suspension of Detention; Law

\section{PENDAHULUAN}

Pasal 1 butir 21 UU RI nomor 8 tahun 1981 tentang Hukum Acara Pidana yang selanjutnya disebut KUHAP menyebutkan bahwa :

"Penahanan adalah penempatan tersangka atau terdakwa ditempat tertentu oleh penyidik atau penuntut umum atau hakim dengan penetapannya, dalam hal serta menurut cara yang diatur dalam undang-undang ini.

Selanjutnya dalam pasal 22 ayat 1 KUHAP, penahanan tersebut dibedakan 3 jenis penahanan yang didasarkan pada tempat dan cara pelaksanaan penahanan itu, yaitu :

1. Apabila penahanan itu dilaksanakan di rumah tahanan Negara maka jenis penahanannya disebut penahanan rumah Tahanan Negara.

2. Penahanan rumah, penahanan rumah dilaksanakan di rumah tempat tinggal atau rumah kediaman tersangka atau terdakwa dengan mengadakan pengawasan terhadapnya untuk menghindarkan segala sesuatu yang dapat 
P-ISSN 2580 - 7781

E-ISSN 2615 - 3238

menimbulkan kesulitan dalam penyidikan, penuntutan atau pemeriksaan di sidang pengadilan (pasal 22 ayat 2).

3. Penahanan kota, penahanan kota dilaksanakan di kota tempat tinggal atau tempat kediaman tersangka atau terdakwa dengan kewajiban bagi tersangka atau terdakwa melapor diri pada waktu yang ditentukan (pasal 22 ayat 3).

Selanjutnya menurut pasal 31 ayat 1 KUHAP, penahanan ini dapat ditangguhkan yaitu atas permintaan tersangka atau terdakwa, penyidik atau penuntut umum atau hakim, sesuai dengan kewenangan masing-masing dapat mengadakan penangguhan penahanan dengan atau tanpa jaminan orang berdasarkan syarat yang ditentukan.

Dalam penjelasan pasal 31 KUHAP disebutkan bahwa yang dimaksud dengan syarat yang ditentukan ialah wajib lapor, tidak keluar rumah atau kota. Pada umumnya tersangka atau terdakwa banyak yang mengajukan permohonan penangguhan penahanan pada aparat hukum yang berwenang memberikan penangguhan penahanan ini, tetapi permohonan ini lebih banyak yang ditolak dari pada yang dikabulkan. Meskipun para tersangka atau terdakwa tersebut bersedia dan sanggup memenuhi semua syarat yang diajukan kepada mereka.

Alasan penolakan permohonan penangguhan penahanan disebabkan oleh adanya anggapan dari aparat hukum yang berwenang tersebut bahwa seorang tersangka atau pelaku tindak pidana harus ditahan karena adanya kekhawatiran tersangka atau pelaku tindak pidana akan melarikan diri ataupun akan menghilangkan barang bukti. Atas alasan inilah pada umumnya permohonan penangguhan penahanan ditolak oleh aparat hukum yang memiliki kewenangan.

Demikian pula sebaliknya pemberian penangguhan penahanan oleh aparat hukum yang berwenang, dimungkinkan sewaktu-waktu dapat dicabut kembali, sepanjang tersangka atau terdakwa mengkhawatirkan melarikan diri atau melanggar syarat-syarat yang sudah ditetapkan atau ditentukan.

Berdasarkan uraian latar belakang tersebut diatas, maka perlu dikaji studi penelitian tentang Tinjauan KUHAP tentang penangguhan penahanan. Tujuan penelitian ini adalah untuk meninjau pelaksanaan penangguhan penahanan menurut KUHAP. 
P-ISSN $2580-7781$

E-ISSN 2615 - 3238

\section{METODE PENELITIAN}

Metode yang dipergunakan dalam penelitian ini adalah metode deskriptif analitis dengan pendekatan utamanya yuridis normatif. Deskriptif analitis berarti menggambarkan dan melukiskan sesuatu yang menjadi obyek penelitian secara kritis melalui analisis yang bersifat kualitatif. Oleh karena yang ingin dikaji berada dalam ruang lingkup ilmu hukum, maka pendekatan normative tersebut, meliputi: asas-asas hukum, sinkronisasi peraturan perundang- undangan, termasuk usaha penemuan hukum inconcreto.

Dalam konteks penelitian ini, maka pendekatan dilakukan terhadap norma hukum yang terdapat di dalam beberapa peraturan seperti KUHAP dan peraturan pemerintah nomor 27 tahun 1983 dan UU RI nomor 8 tahun 1981 tentang Hukum Acara Pidana.

\section{HASIL PENELITIAN DAN PEMBAHASAN}

\section{Pengertian Penahanan Obyektif dan Penahanan Subyektif Dalam} Hubungannya dengan Pelaksanaan Penangguhan Penahanan

Dalam membahas pelaksanaan penangguhan penahanan maka tidak akan terlepas dari unsur penahanan obyektif dan penahanan subyektif. Disebut dengan penahanan obyektif karena undang-undang sendiri telah menentukan pasal-pasal mengenai jenis tindak pidana apa yang dapat dilakukan penahanan, tidak terhadap semua tindak pidana dapat dilakukan penahanan atas tersangka atau tedakwa.

Sedangkan unsur penahanan subyektif adalah menitik beratkan kepada keadaan atau keperluan penahanan itu sendiri. Unsur keadaan atau keperluan penahanan yang dimaksud ditentukan dalam pasal 21 ayat 1 KUHAP, yang menyebutkan : "perintah penahanan atau penahanan lanjutan dilakukan terhadap seorang tersangka atau terdakwa yang diduga keras melakukan tindak pidana berdasarkan bukti yang cukup dalam hal adanya keadaan yang menimbulkan kekhawatiran bahwa tersangka atau terdakwa akan melarikan diri, merusak atau menghilangkan barang bukti dan mengulangi tindak pidana."

Dengan demikian dapat dikatakan bahwa syarat penahanan obyektif dan subyektif dapat berpengaruh pula dalam pelaksanaan penangguhan penahanan. Dapat atau tidaknya dilaksanakan penangguhan penahanan adalah tergantung dari pejabat yang memberikan penangguhan penahanan. Dalam hal ini pejabat yang 
P-ISSN 2580 - 7781

E-ISSN 2615 - 3238

berwenang memperhatikan adanya unsur penahanan obyektif dan unsur penahanan subyektif.

Pengaruh syarat penahanan obyektif dan subyektif dalam pemberian penangguhan penahanan terletak pada pertimbangan pejabat tersebut pada saat akan menangguhkan penahanan terhadap seorang tersangka atau terdakwa dimana sebelumnya pejabat harus mempertimbangkan ancaman pidana dari tindak pidana yang telah dilakukan tersangka atau terdakwa, tindak pidana apakah yang telah dilakukan tersangka atau terdakwa, apakah dengan ditangguhkan penahanannya tersangka atau terdakwa tersebut tidak akan melarikan diri yang akhirnya akan menyulitkan pemeriksaan terhadap perkaranya.

\section{Bagi Tersangka atau Terdakwa}

Menurut pertimbangan tersangka atau terdakwa bahwa ia dapat memintakan/permohonan penangguhan penahanan dengan melihat dari tindak pidana yang dilakukannya sendiri, tersangka memperkirakan apakah tindak pidananya dapat dimintakan penangguhan penahanan atau tidak, dalam hal ini tersangka atau terdakwa melihat dari berat atau ringannya tindak pidana yang telah dilakukan.

Alasan lain karena tersangka atau terdakwa mungkin masih sekolah. Pertimbangan tersebut dapat digunakan tersangka untuk memintakan penangguhan penahanan.

\section{Pemberian Penangguhan Penahanan Oleh Aparat Hukum Yang Berwenang}

Pertimbangan bagi pejabat yang berwenang mengenai dapat tidaknya pelaksanaan penangguhan penahanan diberikan kepada tersangka atau terdakwa tergantung dari pejabat yang berwenang. Dalam hal ini pejabat tersebut akan mempertimbangkan apakah tindak pidana yang dilakukan tersangka atau terdakwa dapat ditangguhkan penahanan atau tidak, kalau dapat ditangguhkan maka pejabat yang berwenang akan memberikan penangguhan penahanan, tetapi kalau tidak maka permintaan / permohonan penangguhan penahanan itu akan ditolak.

Pertimbangan lain bagi pejabat tersebut dalam memberikan penangguhan penahanan dengan mempertimbangkan juga adanya syarat penahanan obyektif dan syarat penahanan subyektif. Para pejabat yang berwenang (penyidik, penuntut umum atau hakim) juga yang akan mempertimbangkan faktor-faktor lain, seperti 
P-ISSN 2580 - 7781

E-ISSN 2615 - 3238

jaminan penangguhan penahanan yang berupa jaminan orang atau jaminan uang, tetapi dalam prakteknya, pelaksanaan penangguhan penahanan lebih banyak menggunakan jaminan orang bila dibandingkan dengan jaminan berupa uang.

Faktor lain dipandang dari segi manfaat. Manfaat apa yang diperoleh oleh tersangka atau terdakwa dengan ditangguhkannya penahanan itu. Contoh: seorang tersangka atau terdakwa yang masih sekolah atau status pelajar, maka apabila penangguhan penahanan diberikan, ia akan tetap dapat mengikuti pelajaran selama penangguhan penahanan. Jadi penangguhan penahanan ini dirasakan sekali manfaatnya oleh tersangka atau terdakwa.

Demikian pula sebaliknya, pejabat penyidik, penuntut umum atau hakim, sewaktu-waktu dapat mencabut penangguhan dalam hal tersangka atau terdakwa melanggar syarat sebagaimana dimaksud di dalam pasal 31 ayat 2 KUHAP. Ketentuan pasal 31 KUHAP tersebut dapat memberikan pedoman kepada para pejabat yang berwenang, bahwa mereka dapat bertindak melakukan pencabutan penangguhan penahanan dalam hal tersangka atau terdakwa telah melanggar syarat-syarat yang ditentukan oleh pejabat yang bersangkutan.

Jika tersangka atau terdakwa selama penangguhan penahanan yang diberikan kepada tersangka atau terdakwa tidak melanggar syarat-syarat yang ditentukan dalam pelaksanaan penangguhan penahanan, maka tidak ada alasan bagi pejabat yang bersangkutan untuk bertindak melakukan pencabutan penangguhan penahanan.

\section{Pelaksanaan Penangguhan Penahanan Dengan Jaminan Orang dan atau Jaminan Uang}

\section{Pelaksanaan Penangguhan Penahanan Dengan Jaminan Orang}

Arti dari jaminan penangguhan penahanan dengan jaminan orang adalah perjanjian penangguhan penahanan dimana seseorang bertindak dan menyerahkan dirinya dengan sukarela sebagai jaminan. Orang yang menjadi jaminan ini bisa penasehat hukumnya atau keluarganya maupun orang lain yang tidak mempunyai hubungan apapun dengan tersangka atau terdakwa.

Penjamin akan memberikan pernyataan dan kepastian kepada pejabat yang berwenang memberi penangguhan penahanan bahwa ia (penjamin) bersedia 
P-ISSN 2580 - 7781

E-ISSN 2615 - 3238

bertanggung jawab memikul segala resiko dan akibat yang timbul apabila tersangka atau terdakwa melarikan diri.

Tata cara pelaksanaannya:

1. Mencantumkan identitas sebagai penjamin, dicantumkan secara jelas dalam perjanjian penangguhann penahanan.

2. Pejabat yang berwenang menetapkan besarnya jumlah uang yang harus ditanggung oleh penjamin, sebagai pengganti apabila selama pemberian masa penangguhan penahanan tersangka atau terdakwa melarikan diri.

3. Penerbitan surat perintah penangguhan penahanan dari pejabat yang berwenang berdasarkan atas surat jaminan dari penjamin.

Jadi disamping surat perjanjian pelaksanaan penangguhan penahanan, memuat secara jelas identitas orang yang menjamin, juga memuat besarnya uang tanggungan dari orang yang menjamin yang sudah ditetapkan oleh pejabat yang berwenang.

Uang jaminan baru disetorkan apabila tersangka atau terdakwa melarikan diri, maka uang jaminan ini menjadi milik negara. Penyetoran uang jaminan masih digantungkan pada peristiwa lain, yaitu apabila tersangka atau terdakwa melarikan diri dan lewat 3 bulan juga tidak diketemukan. Jadi selama tersangka atau terdakwa tidak melarikan diri belum timbul kewajiban hukum untuk menyetor uang jaminan.

\section{Pelaksanaan Penangguhan Penahanan Dengan Jaminan Uang}

Pelaksanaan jaminan penangguhan penahanan dengan jaminan uang disebutkan dalam pasal 35 ayat (1) dan (2) penjelasan peraturan pemerintah nomor 27 tahun 1983 tentang pelaksanaan KUHAP yang disebutkan sebagai berikut :

1. Uang jaminan penangguhan penahanan yang ditetapkan oleh pejabat yang berwenang sesuai dengan tingkat pemeriksaan, disimpan di Kepaniteraan Pengadilan Negeri.

2. Apabila tersangka atau terdakwa melarikan diridan setelah lewat waktu 3 (tiga) bulan tidak diketemukan, uang jaminan tersebut menjadi milik negara dan disetor ke kas negara. 
P-ISSN 2580 - 7781

E-ISSN 2615 - 3238

Uang jaminan ini disimpan di Kepaniteraan Pengadilan Negeri dan pejabat yang memberikan penangguhan penahanan tidak berwenang umtuk menyimpan uang jaminan ini, sekalipun yang memberikan penangguhan penahanan seorang penyidik, penuntut umum atau hakim Pengadilan Negeri, atau Hakim Pengadilan Tinggi atau Hakim Mahkamah Agung.

Penyetoran uang jaminan dilakukan oleh pemohon atau melalui penasehat hukumnya atau keluarganya.

Penyetoran dilakukan berdasarkan formulir penyetoran yang dikeluarkan oleh pejabat yang berwenang. Uang jaminan tersebut baru dapat kembali kepada pemohon setelah perjanjian penangguhan penahanan berakhir.

Dalam hal pemohon melanggar syarat-syarat yang ditentukan dalam perjanjian pelaksanaan penangguhan penahanan berupa tindakan melarikan diri, maka uang jaminan yang dititipkan di Kepaniteraan Pengadilan Negeri dengan sendirinya berubah menjadi milik negara dan di setor ke kas negara oleh panitera yang bersangkutan.

\section{KESIMPULAN}

Berdasarkan uraian dan bahasan tersebut di atas maka studi hasil penelitian ini dapat disimpulkan bahwa pelaksanaan penangguhan penahanan menurut KUHAP dan P.P no 27 tahun 1983 tentang pelaksanaan KUHAP adalah sebagai berikut:

1. Pelaksanaan penangguhan penahanan dapat berupa jaminan orang dan atau dengan jaminan uang.

2. Akan tetapi penangguhan penahanan sewaktu-waktu dapat dicabut kembali oleh pejabat yang berwenang sepanjang tersangka atau terdakwa melanggar persyaratan-persyaratan yang sudah ditentukan.

Dengan demikian permohonan penangguhan penahanan dikabulkan atau tidak adalah tergantung pada keyakinan pejabat yang berwenang berdasarkan beberapa pertimbangan apakah tersangka atau terdakwa akan melarikan diri, menghilangkan barang bukti atau mengulangi lagi perbuatan pidana atau tidak. 
P-ISSN 2580 - 7781

E-ISSN 2615 - 3238

\section{DAFTAR PUSTAKA}

Andi Hamzah, KUHP dan KUHAP, cet. Ke-duabelas, Penerbit Rineka Cipta, Jakarta 2005.

Atmasasmita Romli, Bunga Rampai Hukum Acara Pidana, Binacipta, Jakarta, 1986.

Andi Hamzah, Pengantar Hukum Acara Pidana, Ghalia Indonesia, Jakarta, 1987.

Bambang Poernomo, Orientasi Hukum Acara Pidana Indonesia, Amarta Buku, Jakarta, 1988.

Oemar Seno, Hukum Acara Pidana Hukum Dalam Prospeksi, Erlangga, Surabaya, 1981.

Peraturan Pemerintah Nomor 27 Tahun 1983 Tentang Pelaksanaan KUHAP. 